\title{
SEMIAUTOMATIC IRRIGATION MANAGEMENT IN TOMATO
}

\author{
Claudinei F. Souza ${ }^{1 *}$, Maria E. S. Conchesqui ${ }^{2}$, Marília B. da Silva ${ }^{2}$ \\ ${ }^{1 *}$ Corresponding author. Federal University of São Carlos/ Araras - SP, Brazil. \\ E-mail: cfsouza@ufscar.br. ORCID ID: https://orcid.org/0000-0001-9501-0794
}

\section{KEYWORDS}

digital assistant, irrigation management, TDR, capacitance, Solanum lycopersicum L.

\begin{abstract}
The use of new technologies to meet the demands of the agricultural market is increasing; however, technical information on application is scarce for some areas of knowledge, including irrigation management. The objective of this study is to evaluate an automatic irrigation system with capacitance sensors connected to a local wireless network for the semiautomatic management of irrigation in tomato crops compared with a manual control system based on time-domain reflectometry (TDR)-type sensors. The experiments were carried out in a protected environment, and the seedlings were transplanted following surface drip lines. The study adopted a completely randomized block design consisting of two treatments and 12 repetitions, totaling 24 subplots. The evaluated treatments were an irrigation management system with TDR sensors and a manually-programmed controller, and an irrigation management system with capacitance sensors and a semiautomaticallyprogrammed controller connected to a digital assistant. Quantitative and qualitative parameters as well as the green and dry matter production were evaluated in each treatment. The results indicated that both sensors were effective in managing irrigation in tomato crops. Furthermore, both systems were accurate, and the Alexa ${ }^{\circledR}$ digital assistant was efficient in programming the GreenIQ ${ }^{\circledR}$ semiautomatic system by voice commands.
\end{abstract}

\section{INTRODUCTION}

Tomatoes are one of the most consumed vegetables in Brazil and worldwide and are relevant in the Brazilian market because of their high commercial value. In the segment of table tomatoes, the cultivation of cherry tomatoes has increased in Brazil in recent years, improving producers' income compared to regular-size tomatoes (Andrade et al., 2017).

Three types of cherry tomatoes are commercially available to date: Cherry, Grape, and Italian, which differ in taste, size, shape, color, and the amount of soluble solids. Grape tomatoes have a higher amount of soluble solids than the other types and are valued for their sweetness (Negrisoli et al., 2015).

The increase in tomato consumption stimulates the search for higher fruit yield and quality. Therefore, protected cultivation systems are crucial because they change the microclimate, ensuring production in unfavorable times by reducing climatic adversities. In Brazil, protected cultivation gained prominence by allowing normalizing tomato production throughout the year, consequently reducing price oscillations in the off-season.

Irrigation is necessary in protected cultivation systems. Among the different irrigation systems available, localized irrigation has been used to promote the rational use of water. This system is characterized by applying small volumes of water at high frequency, forming a wet zone near the roots, which keeps the soil moisture close to field capacity, avoiding water loss through percolation and evaporation. Drip systems are the most suitable localized irrigation systems for tomato cultivation, allowing increased productivity and saving water resources (Andrade et al., 2017; Silva et al., 2015).

\footnotetext{
${ }^{2}$ Federal University of São Carlos/ Araras - SP, Brazil.

Area Editor: Fabio Henrique Rojo Baio

Received in: 1-31-2019

Accepted in: 6-27-2019
} 
Soil water storage varies with rainfall, irrigation level, drainage, evaporation, and soil management practices. Therefore, methods that accurately and instantaneously assess variations in water storage under different soil conditions are essential. Water storage can be measured by gravimetry, which is a direct method but is destructive and does not allow automation. Moreover, indirect methods can estimate soil water content by analyzing physical properties without the need to collect samples (Bizari et al., 2016; Souza et al., 2016).

Electronic sensors are very accurate but can produce discordant results depending on build quality and/or calibration. Nonetheless, the correct calibration under local field conditions can ensure practical and accurate readings of soil water levels (Gava et al., 2016).

Time-domain reflectometry (TDR) and capacitance sensing are indirect methods of measuring soil moisture that make estimates based on the time of propagation of electromagnetic waves in the soil. Both techniques estimate volumetric moisture and electrical conductivity, enabling the management of soil water and nutrients (Souza et al., 2016).

The main advantages of capacitance sensors are their low cost relative to TDR and the interaction with irrigation controllers and digital assistants for decision-making about the time and duration of irrigation. Capacitance sensors read the dielectric constant of the soil and function as electronic capacitors. Moreover, these sensors are useful because of their high flexibility in the operating frequency, allowing multiple and repeated readings without destroying soil samples (Ramos et al., 2014; Souza et al., 2016).

These technologies are widely used in other countries and are feasible for farmers, resulting in labor reduction and the sustainable use of natural agricultural resources in protected environments. The objective of this study is to evaluate an automatic irrigation system with capacitance sensors connected to a local wireless network for the semiautomatic management of irrigation in cherry tomato (Solanum lycopersicum L. cv. Milla, Grape Cluster) compared with a TDR-based manual control system.

\section{MATERIAL AND METHODS}

The experiments were carried out in a greenhouse from the Department of Natural Resources and Environmental Protection of the Center for Agricultural Sciences of the Federal University of São Carlos, located in Araras, state of São Paulo, Brazil. The greenhouse (width, $6.4 \mathrm{~m}$; length, $20.0 \mathrm{~m}$; height, $5.0 \mathrm{~m}$ ) has a galvanized steel structure covered with polyethylene $(150 \mu \mathrm{m})$ in the ceiling and sides.

The soil in the greenhouse is clayey Red Latosol, and the climate is type Cwa according to Köppen's classification: mesothermal with hot and humid summers and dry winters (Urbano et al., 2017).

The study adopted a completely randomized block design consisting of two treatments and 12 repetitions, totaling 24 subplots. Each subplot corresponded to $50 \%$ of a $5.4 \mathrm{~m}^{2}$ plot and, because of the possibility of using an environmental gradient in the greenhouse, the plots were arranged sequentially and alternately (Figure 1). The following treatments were analyzed: T1, an irrigation control system with TDR sensors and a manuallyprogrammed controller; T2, an irrigation management system with capacitance sensors and a semiautomaticallyprogrammed controller. The sensors were calibrated in the laboratory using a standard gravimetric method.

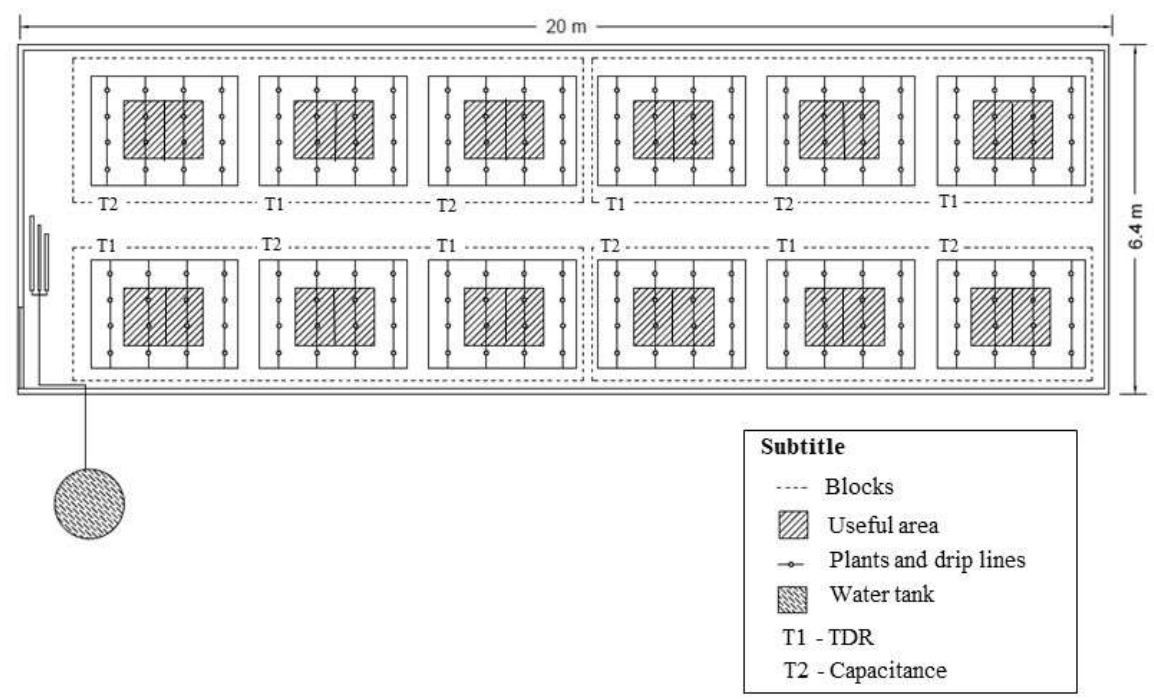

FIGURE 1. Diagram of the experimental area with subplots in the greenhouse.

The soil was sampled by collecting 20 subsamples in the $0-20 \mathrm{~cm}$ soil layer in a zigzag pattern using a screw auger. The final sample containing the subsamples was taken to the laboratory for chemical and physical analyses to evaluate the irrigation management system and calculate the nutritional dosage. 
TABLE 1. Physical and chemical characteristics of the soil used for tomato cultivation in the $0-0.20 \mathrm{~m}$ layer.

\begin{tabular}{|c|c|c|}
\hline Soil characteristics & Unit & Composition \\
\hline Sand & $\%$ & 19 \\
\hline Silt & $\%$ & 31 \\
\hline Clay & $\%$ & 50 \\
\hline Field capacity & $\mathrm{m}^{3} \mathrm{~m}^{-3}$ & 0.32 \\
\hline Permanent wilting point & $\mathrm{m}^{3} \mathrm{~m}^{-3}$ & 0.17 \\
\hline Total porosity & $\mathrm{m}^{3} \mathrm{~m}^{-3}$ & 0.50 \\
\hline Soil density & $\mathrm{kg} \mathrm{m}^{-3}$ & 1,300 \\
\hline Soil particle density & $\mathrm{kg} \mathrm{m}^{-3}$ & 2,580 \\
\hline Basic infiltration rate & $\mathrm{cm} \mathrm{h}^{-1}$ & 13.20 \\
\hline $\mathrm{pH}$ & - & 5.30 \\
\hline Phosphorus & $\mathrm{mg} \mathrm{dm}{ }^{-3}$ & 32.00 \\
\hline Organic matter & $\%$ & 33 \\
\hline Potential acidity & $\mathrm{mmol}_{\mathrm{c}} \mathrm{dm}^{-3}$ & 58.00 \\
\hline Potassium & $\mathrm{mmol}_{\mathrm{c}} \mathrm{dm}^{-3}$ & 5.2 \\
\hline Calcium & $\mathrm{mmol}_{\mathrm{c}} \mathrm{dm}^{-3}$ & 30.00 \\
\hline Magnesium & $\mathrm{mmol}_{\mathrm{c}} \mathrm{dm}^{-3}$ & 20.00 \\
\hline Sum of bases & $\mathrm{mmol}_{\mathrm{c}} \mathrm{dm}^{-3}$ & 55.20 \\
\hline Cation exchange capacity & $\mathrm{mmol}_{\mathrm{c}} \mathrm{dm}^{-3}$ & 113.20 \\
\hline Base saturation & $\%$ & 49 \\
\hline Sulfur & $\mathrm{mg} \mathrm{dm}{ }^{-3}$ & 72.00 \\
\hline Boron & $\mathrm{mg} \mathrm{dm}{ }^{-3}$ & 0.10 \\
\hline Copper & $\mathrm{mg} \mathrm{dm}{ }^{-3}$ & 4.80 \\
\hline Iron & $\mathrm{mg} \mathrm{dm}^{-3}$ & 92.00 \\
\hline Manganese & $\mathrm{mg} \mathrm{dm}{ }^{-3}$ & 1.80 \\
\hline Zinc & $\mathrm{mg} \mathrm{dm}^{-3}$ & 1.40 \\
\hline
\end{tabular}

As recommended in the Technical Bulletin 100 (Raij et al., 1997), liming was performed to increase base saturation by $80 \%$, and soil acidity was corrected using limestone with a total relative neutralization power of $85.6 \%$.

Twelve plots (width, $2.7 \mathrm{~m}$; length, $2.0 \mathrm{~m}$; height, 0.3 $\mathrm{m})$ with a total area of $5.4 \mathrm{~m}^{2}$ were prepared. A total of 3.32 $\mathrm{kg}$ of limestone was applied in each plot according to the results of soil analysis. Four lateral drip lines with a spacing of $0.7 \mathrm{~m}$ from each other, spacing of $0.5 \mathrm{~m}$ between drippers, and a flow rate of $1.6 \mathrm{~L} \mathrm{~h}^{-1}$ were used in each plot.

The drippers were subjected to an application uniformity test and had a uniformity of $96.5 \%$. This value was obtained by calculating the Christiansen's uniformity coefficient according to the methodology of Cunha et al. (2014).

The seedlings of tomato (Solanum lycopersicum L. cv. Milla, Grape Cluster) were produced in a 128-cell tray and transplanted on February 21, 2018, when they presented the fourth definitive leaf. Sixteen seedlings were planted per plot with a plant spacing of $0.50 \mathrm{~m}$ and row spacing of 0.70 $\mathrm{m}$, totaling an area of $0.35 \mathrm{~m}^{2}$ per plant.

Fertilization was performed following the recommendation of the Technical Bulletin 100 (Raij et al., 1997). Controlled release polymers (potassium nitrate and urea; Haifa's Multicote ${ }^{\circledR}$ Agri and Multigro $\left.{ }^{\circledR}\right)$ and single superphosphate were mixed into the soil at the time of planting; for this reason, the amount of fertilizer used was the sum of the amount recommended for planting and mulching. ${ }^{3}$ The seedlings were transplanted after fertilization.

The tomato vines were staked and trained to a vertical trellising system following the crop rows, and the vines were slightly fastened to raffia fibers using ribbons to ensure that the knots did not strangle the plants and allowing their free growth. Sprouting was performed by pruning off the suckers growing in the leaf axils using chlorinedisinfected shears in each stem to obtain a single stem. Weeds were controlled manually. The experiment was conducted until the sixth fruiting cluster, keeping the pruned plants at the height of approximately $1.80 \mathrm{~m}$.

Considering [eq. (1)] to return moisture to soil field capacity $\left(\theta_{\mathrm{CC}}=0.32 \mathrm{~m}^{3} \mathrm{~m}^{-3}\right)$, irrigation control using a manual or semiautomatic program was performed using two types of electromagnetic sensors to estimate soil moisture: TDR at T1 and capacitance sensing at T2.

$$
\mathrm{L}=\left(\theta_{C C}-\theta\right) \times \mathrm{z} \times 1000
$$

Where:

$\mathrm{L}$ is the water depth $(\mathrm{mm})$;

$\theta$ is the soil moisture $\left(\mathrm{m}^{3} \mathrm{~m}^{-3}\right)$,

$\mathrm{z}$ is the effective root depth in the first month at $\mathrm{z}=$ $0.10 \mathrm{~m}$ and in subsequent months at $\mathrm{z}=0.20 \mathrm{~m}$.

${ }^{3}$ Trademark references do not constitute endorsement by the authors. 
To manage irrigation by TDR, two probes were placed in each plot at a depth of $0-0.10 \mathrm{~m}$ close to the plants in the useful area $(0.10 \mathrm{~m})$. The probes were $0.20 \mathrm{~m}$ long and were positioned diagonally to reach a depth of $0.10 \mathrm{~m}$ (Figure 2A), allowing comparing these measurements with those of capacitance sensors with a height of $0.10 \mathrm{~m}$ (Figure 2B). This restriction in soil depth is because tests demonstrated the lack of Bluetooth connection between buried capacitance sensors and control panel.

Irrigation management was performed by estimating soil moisture on Mondays, Wednesdays, and Fridays using different sensors. The soil moisture was in field capacity at the time of seedling transplantation.
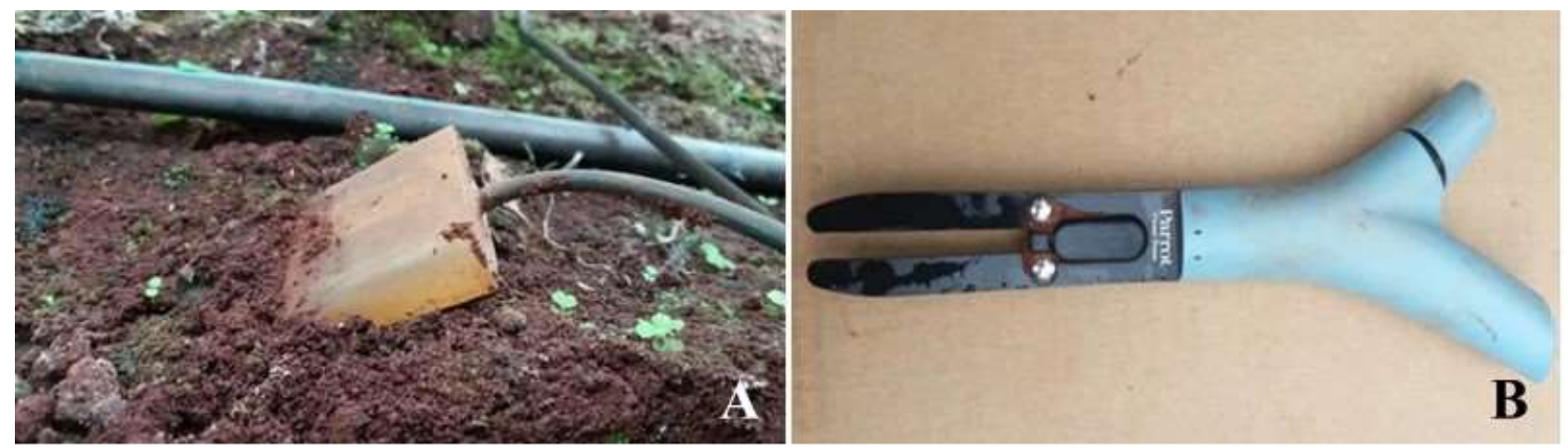

FIGURE 2. Sensors used for irrigation management. (A) TDR probes positioned diagonally in the soil. (B) A Parrot Flower Power® capacitance sensor.

A TDR100 reflectometer (Campbell Scientific ${ }^{3}$, Logan-Utah; Figure 3A) was used to determine soil moisture using the calibration equations of Souza et al. (2017) (Equation 2) for the same soil type. Equation 1 was used for managing these treatments, and the irrigation controller AC-4 Galcon ${ }^{3}$ was programmed manually (Figure 3B).
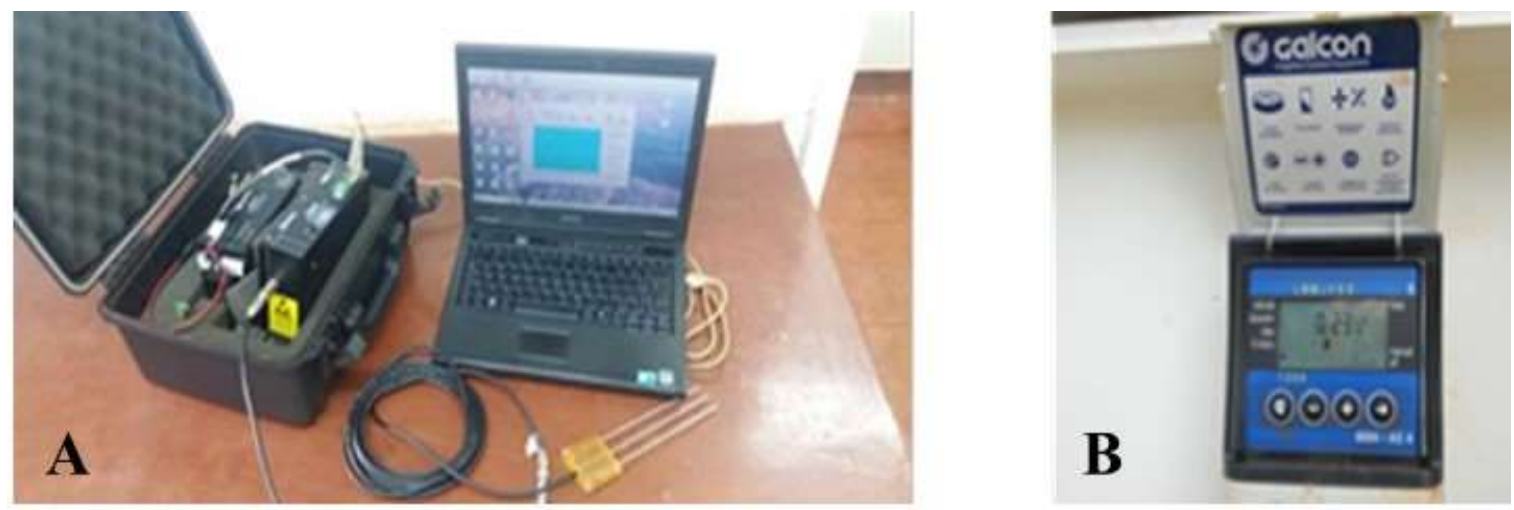

FIGURE 3. Equipment used in T1. (A) TDR 100 reflectometer. (B) Galcon manual controller.

$$
\theta=0.000005 \mathrm{Ka}^{3}-0.0003 \mathrm{Ka}^{2}+0.0161 \mathrm{Ka}+0.0132
$$

Where:

$\theta$ is the soil moisture $\left(\mathrm{m}^{3} \mathrm{~m}^{-3}\right)$,

$\mathrm{Ka}$ is the apparent dielectric constant of the soil (dimensionless).

Parrot Flower Power ${ }^{3}$ capacitance sensors were used, which can measure soil moisture and temperature, solar radiation intensity, air temperature, and fertilizer requirement.

Irrigation control was performed using the calibration equation of Simione et al. (2016) (Equation 3).

$$
\theta=(1.1142 \bar{\theta})-0.1019
$$

Where:

$$
\begin{aligned}
& \theta \text { is the soil moisture }\left(\mathrm{m}^{3} \mathrm{~m}^{-3}\right) \\
& \bar{\theta} \text { is the average soil moisture }\left(\mathrm{m}^{3} \mathrm{~m}^{-3}\right) .
\end{aligned}
$$

The semiautomatic system was employed by programming the GreenIQ ${ }^{\circledR}{ }^{3}$ irrigation controller (Figure 4A), which estimated soil moisture using Bluetooth capacitance sensors. The soil moisture values were analyzed using the GreenIQ ${ }^{\circledR}$ application via smartphone, and the users were informed through local wireless networks about the time and duration of irrigation. This system also provided weather data to improve user decision-making (Figure 4B). This controller was linked to an Amazon $^{3}$ Alexa ${ }^{\circledR}$ personal assistant for managing irrigation by voice commands (Figure 4C). A flowchart of the system is shown in Figure 5.

The GreenIQ controller can work automatically by making all decisions on the time and duration of irrigation; however, this function was set to semiautomatic. In this mode, the system waits for user confirmation to start irrigation, and the operator can confirm the process by voice commands using the digital assistant or the smartphone application. 


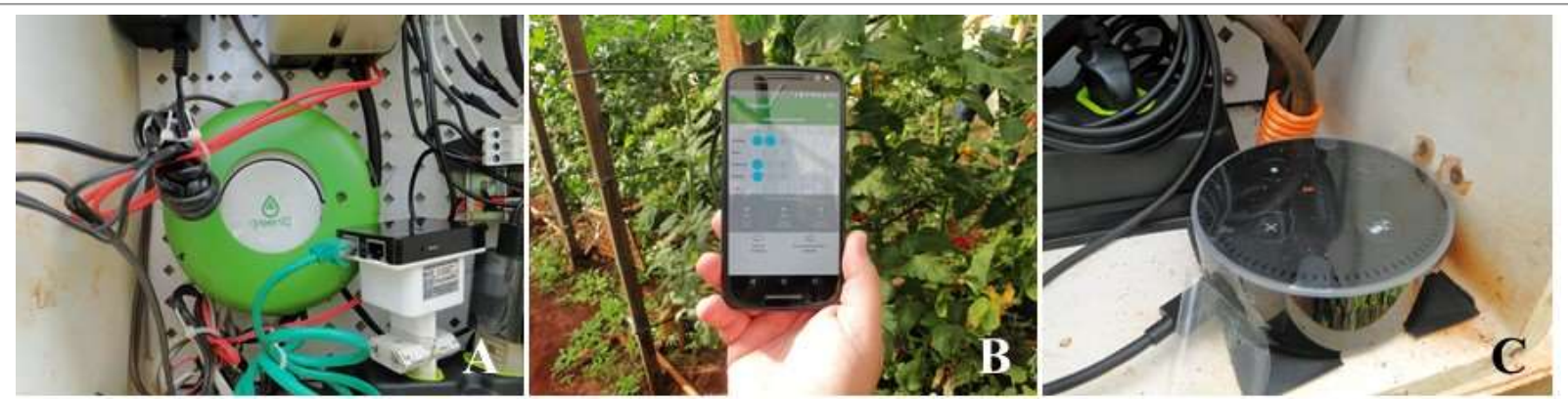

FIGURE 4. Equipment used in T2. (A) GreenIQ ${ }^{\circledR}$ controller. (B) Irrigation control graphical interface. (C) Amazon ${ }^{\circledR}$ Alexa ${ }^{\circledR}$ personal assistant.

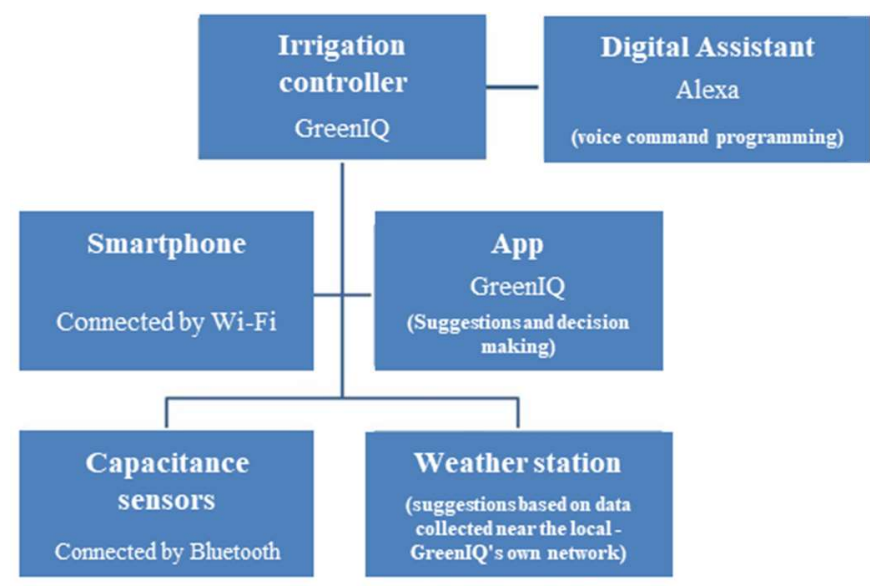

FIGURE 5. Flowchart of the semiautomatic irrigation control system.

The plants terminal buds were pruned upon reaching the sixth fruiting cluster, and the fruits were harvested once a week and analyzed. Quantitative and qualitative parameters were analyzed. The number of fruits in all productive stems was counted in each harvest. Fruit mass was measured using a precision scale $(0.001 \mathrm{~g})$, and all fruits of each plant were weighed. Soluble solids were determined in three fruits per plant by measuring the ${ }^{\circ}$ Brix using a refractometer. The $\mathrm{pH}$ of the extract of all fruits of one plant was measured using a $\mathrm{pH}$ meter.

Data analysis was performed using Excel software. The $t$-test $(\mathrm{p}<0.05)$ was applied to compare the average irrigation depths obtained daily in each treatment. In addition, the same test was used to compare quantitative and qualitative data on fruit characteristics and green and dry matter production.

\section{RESULTS AND DISCUSSION}

During the study period, the average air temperature inside the greenhouse was $21.7^{\circ} \mathrm{C}$, with a maximum of 31.6 ${ }^{\circ} \mathrm{C}$ and minimum of $12.4{ }^{\circ} \mathrm{C}$. The average relative humidity was $83.6 \%$, with a maximum of $98.3 \%$ and a minimum of $36.2 \%$. These values are suitable for tomato growth, and the average temperature should be between 22 and $28{ }^{\circ} \mathrm{C}$. Nonetheless, tomato plants tolerate variations between 10 and $34{ }^{\circ} \mathrm{C}$, and plant growth is reduced at temperatures below $12^{\circ} \mathrm{C}$ (Araújo et al., 2016).

Soil moisture sensors, TDR, and capacitance sensors were useful in monitoring soil moisture between permanent wilting point and field capacity at a soil depth of $0-0.10 \mathrm{~m}$ (Figure 6).

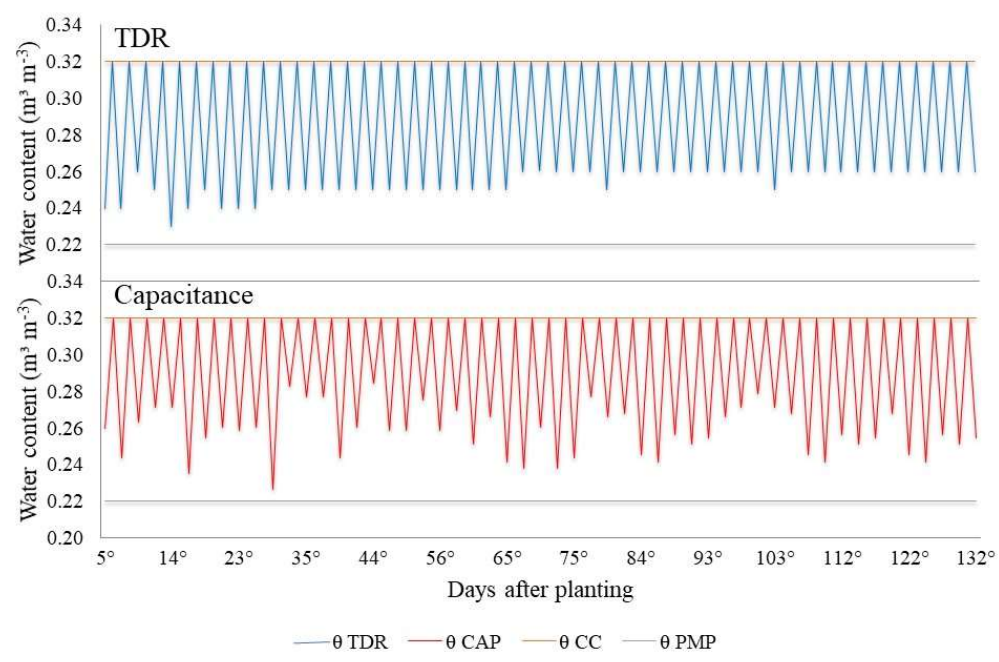

FIGURE 6. Variations in soil moisture during the study period. Average values were estimated using TDR probes and capacitance sensors (FC, field capacity; PWP, permanent wilting point). 
At some time points, soil moisture estimates using capacitance sensors were higher than those using TDR. However, linear regression analysis showed that mean differences between estimates were less than $1 \%$. There was no significant difference $(p=0.638)$ in soil moisture estimates between treatments according to the $t$-test at a level of significance of $5 \%$.
Comparing the irrigation depths used according to soil moisture estimation by sensors, the moisture levels at some time points were overestimated by capacitance sensors and resulted in the application of smaller irrigation depths by the semiautomatic system (T2) compared to TDR probes. The overlap of the irrigation depths $(\mathrm{mm})$ applied in different treatments is shown in Figure 7.

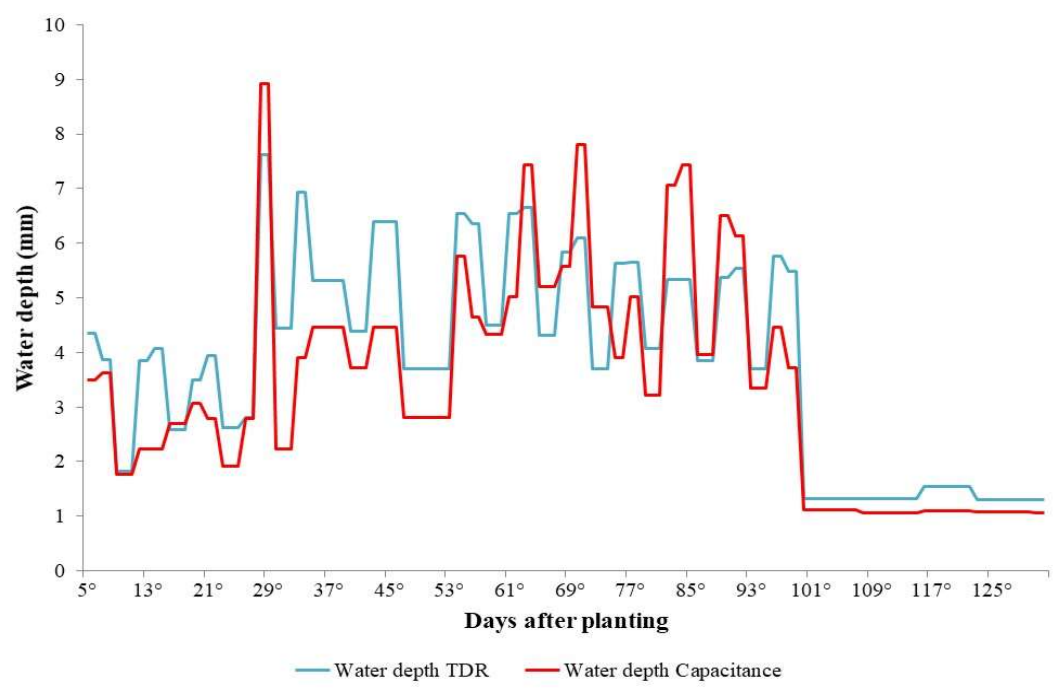

FIGURE 7. Irrigation depths (mm) applied daily after soil moisture estimation by TDR probes (T1) and capacitance sensors (T2).

A $t$-test was used to compare the difference between the sum of the irrigation depths applied daily in different treatments (T1, $500 \mathrm{~mm} ; \mathrm{T} 2,440 \mathrm{~mm})$. The average irrigation depth in $\mathrm{T} 1$ and $\mathrm{T} 2$ was $3.8 \mathrm{~mm}$ and $3.4 \mathrm{~mm}$, respectively. The hypothesis of significant difference was not accepted because the p-value was equivalent to 0.078 .

Souza et al. (2016) and Souza et al. (2013) found that the accuracy of TDR was higher than that of capacitance sensing and highlighted that capacitance sensors worked in frequency ranges more susceptible to errors (30-100 MHz). However, the calibrations performed in the laboratory could minimize the observed errors.

The results indicated that there were no significant differences in the analyzed qualitative and quantitative parameters between $\mathrm{T} 1$ and $\mathrm{T} 2$. It is worth emphasizing that measurements were performed until the sixth fruiting cluster (approximately 130 days after planting), and this decision justifies the low yield compared with commercial production.

TABLE 2. Quantitative and qualitative parameters of tomato fruits grown in a protected environment under irrigation management carried out using different systems: T1, irrigation control system with TDR sensors and a manually-programmed controller; T2, irrigation management system with capacitance sensors and a semiautomatically-programmed controller.

\begin{tabular}{lcccc}
\hline \multirow{2}{*}{ Parameters } & \multicolumn{2}{c}{ System } & \multicolumn{2}{c}{ Test } \\
\cline { 2 - 4 } & $\mathrm{T} 1$ & $\mathrm{~T} 2$ & $\mathrm{M}$-value \\
\hline Average number of fruits per plant & $11.13 \mathrm{a}$ & $12.72 \mathrm{a}$ & $11.92 \mathrm{a}$ & 0.076 \\
Average fruit mass per plant (g) & $82.60 \mathrm{a}$ & $96.74 \mathrm{a}$ & $89.67 \mathrm{a}$ & 0.069 \\
${ }^{\circ}$ Brix & $8.54 \mathrm{a}$ & $8.46 \mathrm{a}$ & $8.50 \mathrm{a}$ & 0.388 \\
pH & $4.32 \mathrm{a}$ & $4.32 \mathrm{a}$ & $4.32 \mathrm{a}$ & 0.978 \\
Yield $\left(\mathrm{kg} \mathrm{ha}^{-1}\right)$ & $2360.09 \mathrm{a}$ & $2749.70 \mathrm{a}$ & $2554.89 \mathrm{a}$ & 0.080 \\
\hline
\end{tabular}

The means followed by the same letter in each line were not significantly different from each other using the Tukey's test $(\mathrm{p}<0.05)$.

The average green and dry matter of leaves, stems, and roots were compared using a $t$-test at a level of significance of $5 \%$, and the results indicated that there were no significant differences in these parameters. 
TABLE 3. Green and dry matter of tomato leaves, stems, and roots grown in a protected environment under irrigation management carried out using different systems: T1, irrigation control system with TDR sensors and a manually-programmed controller; T2, irrigation management system with capacitance sensors and a semiautomatically-programmed controller.

\begin{tabular}{lcccc}
\hline \multirow{2}{*}{ Parameters (g) } & \multicolumn{2}{c}{ System } & \multicolumn{2}{c}{ Test } \\
\cline { 2 - 5 } Green matter of leaves & T1 & T2 & Means & p-value \\
Dry matter of leaves & $347.05 \mathrm{a}$ & $425.67 \mathrm{a}$ & $386.36 \mathrm{a}$ & 0.365 \\
Green matter of stems & $48.59 \mathrm{a}$ & $59.21 \mathrm{a}$ & $53.9 \mathrm{a}$ & 0.283 \\
Dry matter of stems & $317.29 \mathrm{a}$ & $352.91 \mathrm{a}$ & $335.1 \mathrm{a}$ & 0.234 \\
Green matter of roots & $68.19 \mathrm{a}$ & $92.47 \mathrm{a}$ & $80.33 \mathrm{a}$ & 0.066 \\
Dry matter of roots & $135.21 \mathrm{a}$ & $170.69 \mathrm{a}$ & $152.95 \mathrm{a}$ & 0.179 \\
\hline
\end{tabular}

The means followed by the same letter in each line were not significantly different from each other using the Tukey's test ( $\mathrm{p}<0.05)$.

There were no significant differences in tomato crop production between $\mathrm{T} 1$ and $\mathrm{T} 2$.

The results demonstrate that, after adequate calibration, capacitance sensors connected to semiautomatic controllers for irrigation control in agricultural systems are viable methods that can replace TDR in manually-controlled systems and estimate solar radiation intensity and air and soil temperature. Souza et al. (2016) observed that capacitive sensors presented smaller errors than TDR. However, the accuracy of both systems was higher than that of gravimetry.

The responsiveness and precision of the semiautomatic system are higher than those of the manual system, and the former reduces labor by precluding the need for manual sensor readings in the field and increasing the amount of data provided remotely for decision-making about the time and duration of irrigation. However, this technology requires reliable and high-quality local wireless networks, which have significantly improved in recent years but are scarce in rural areas.

The tests performed by programming with voice commands and the Alexa ${ }^{\circledR}$ personal assistant connected to the GreenIQ ${ }^{\circledR}$ semiautomatic controller proved to be efficient and allowed the voice control of irrigation. However, this system cannot be used by most Brazilian farmers because the assistant only responds to English commands.

In addition, voice control was less useful because it was necessary to go to the greenhouse to schedule irrigation, whereas the GreenIQ ${ }^{\circledR}$ semiautomatic controller allows remotely controlling irrigation using a smartphone and a local wireless network.

Therefore, even if the assistant is efficient to program irrigation, the use of the GreenIQ ${ }^{\circledR}$ semiautomatic controller is recommended because of its higher flexibility in the automation of the irrigation system.

\section{CONCLUSIONS}

Capacitance sensors connected to the semiautomatic control of irrigation were as effective as the manual control of irrigation for analyzing quantitative and quantitative parameters and could replace the manually-controlled system for irrigation management in tomato crops. In addition, the Alexa ${ }^{\circledR}$ personal assistant was efficient in programming irrigation using the voice-controlled semiautomatic system.

\section{ACKNOWLEDGMENTS}

The authors gratefully acknowledge São Paulo Research Foundation (FAPESP - 2017/25610-7) and National Council for Scientific and Technological Development (CNPq -307042/2015-4) for the scholarships granted.

\section{REFERENCES}

Andrade AR, Noronha SP, Azevedo PR, Silva PRA, Santos RC (2017) Fertirrigação no cultivo de quatro cultivares de tomate (Lycopersicum sculentum) irrigado por gotejamento. Revista Brasileira de Tecnologia Aplicada nas Ciências Agrárias 10(2):7-21.

Araújo HF, Leal PAM, Zorzeto T, Betin OS, Nunes EF, Servilha GFP (2016) Alterações micrometeorológicas em ambiente protegidos cultivados com mini-tomates orgânico. Irriga 21(2):226-238.

Bizari DR, Grecco KL, Souza CF (2016) Bulbo molhado estimado pela técnica da TDR na irrigação por gotejamento subsuperficial. Revista Brasileira de Agricultura Irrigada 10(2):477-485.

Cunha FN, Silva NF, Teixeira MB, Carvalho JJ, Moura LMF, Santos CC (2014) Coeficientes de uniformidade em sistema de irrigação por gotejamento. Revista Brasileira de Agricultura Irrigada 8(6): 444-454.

Gava R, Silva EE, Baio FHR (2016) Calibração de sensor eletrônico de umidade em diferentes texturas de solo. Brazilian Journal of Biosystems Engineering 10(2):154-162.

Negrisoli RM, Cechinatto FH, Bissoli MJ, Rosestolato LLR, Sabbag OJ (2015) Viabilidade Econômica no Cultivo de Minitomate Sweet Grape no Município de Casa Branca/SP. Enciclopédia Biosfera 11(21):1932-1942.

Raij B, Cantarella H, Quaggio JA, Furlani AMC (1997) Recomendações de adubação e calagem para o Estado de São Paulo. Campinas, Instituto Agronômico/Fundação IAC, $285 \mathrm{p}$. 
Ramos FT, Pivetta F, Matos VAT, Seixas GB, Campelo Júnior JH (2014) Acurácia e calibração de uma sonda de capacitância em um neossolo quartzarênico cultivado com caju. Bioscience Journal 30(6):1631-1641.

Silva AAF, Souza JR, Carvalho WB, Mendonça R, Moreira DA (2015) Distribuição da umidade do solo num sistema irrigado por gotejamento superficial com diferentes inclinações do terreno. Engenharia na Agricultura 23(3):261-269.

Simione JR, Junior JDF, Mendonça TG, Souza CF (2016) Avaliação e calibração de sondas capacitivas wireless. In: Congresso Brasileiro de Engenharia Agrícola.

Florianópolis, Sociedade Brasileira de Engenharia Agrícola, Proceeding...
Souza CF, Pires RCM, Miranda DB, Varallo ACT (2013) Calibração de sondas FDR e TDR para a estimativa da umidade em dois tipos de solo. Irriga 18(4):597-606.

Souza CF, Silva CR, Andrade Junior AS, Coelho EF (2016) Monitoramento do teor de água no solo e em tempo real com as técnicas de TDR e FDR. Irriga 1(1):26-42.

Souza CF, Faez R, Bacalhau FB, Bacarin MF, Pereira TS (2017) In situ monitoring of a controlled release of fertilizers in lettuce crop. Engenharia Agrícola 37(4):656-664.

Urbano VR, Mendonca TG, Bastos RG, Souza CF (2017) Effects of treated wastewater irrigation on soil properties and lettuce yield. Agricultural Water Management 181(1):108-115. 